\title{
Uji Aktivitas Ekstrak Daun Srikaya (Annona squamosa) sebagai Antipiretik pada Tikus Jantan Galur Wistar secara Invivo
}

\section{Activity Test of Srikaya Leaf Extract (Annona squamosa) as an Antipireticin Invivo Wistar Rats}

\author{
Willi Wahyu Timur ${ }^{1}$, Rina Wijayanti ${ }^{1}$, Tuti Awalia Kamil ${ }^{1}$ \\ ${ }^{1}$ Program Studi Farmasi Fakultas Kedokteran Universitas Islam Sultan Agung Semarang \\ Jl. Raya Kaligawe Km. 4, Semarang 50112 \\ Sur-el: willi_wahyu@unissula.ac.id
}

\begin{abstract}
ABSTRAK
Daun Srikaya memiliki khasiat empirik sebagai penurun panas. Daun Srikaya mengandung flavonoid yang mampu menghambat prostaglandin sehingga mempunyai efek antipiretik. Penelitian dilakukan dengan tujuan untuk mengetahui aktivitas antipiretik ekstrak etanolik 70\% daun srikaya (Annona Squamosa L.) pada tikus jantan galur wistar. Penelitian ini menggunakan metode eksperimen dengan rancangan penelitian post test only randomized control group design. Penelitian menggunakan 25 ekor tikus jantan galur wistar, yang dikelompokkan menjadi 5 kelompok secara acak dan tiap kelompok terdiri dari 5 ekor tikus. Setiap kelompok diinjeksi dengan vaksin DPTHb-Hib 0,3 ml secara I.M untuk menimbulkan demam. Kemudian kelompok I, II, III secara berturut-turut sebagai kelompok ekstrak dosis $720 \mathrm{mg} / \mathrm{kgBB}, 1080 \mathrm{mg} / \mathrm{kgBB}$ dan $1440 \mathrm{mg} / \mathrm{KgBB}$. Kelompok IV kontrol positif (parasetamol 6,3 mg/lo0 g BB) dan kelompok V (CMC-Na 0,5\%). Semuanya diberikan secara peroral secara single dose. Pengukuran suhu dilakukan sebelum pemberian vaksin DPT-Hb-Hib, 3 jam setelah pemberian vaksin DPTHb-Hib dan 30 menit sekali setelah perlakuan sampai menit 240. Hasil menunjukkan bahwa terdapat perbedaan yang signifikan antara kelompok kontrol negatif dengan kelompok dosis I, II, III pada menit-90 sampai 240. Kesimpulan yang dapat diambil bahwa ekstrak etanolik $70 \%$ daun srikaya memiliki efek antipiretik pada tikus jantan galur wistar secara in vivo.
\end{abstract}

Kata kunci: antipiretik, ekstrak daun srikaya (Annona Squamosa L), vaksin DPT-Hb-Hib.

\begin{abstract}
Custard apples leaves have empirical properties as heat-reducing properties. Custard apples leaves contain flavonoids that can inhibit prostaglandins so that they have antipyretic effects. The study was conducted to determine the antipyretic activity of ethanolic extract 70\% of custard apples (Annona squamosa L.) leaves in male wistar rats. This study uses an experimental method with post test only randomized control group design. The study used 25 male wistar rats, which were grouped into 5 groups randomly and each group consisted of 5 rats. Each group was injected with $0.3 \mathrm{ml}$ DPT-Hb-Hib vaccine in I.M to cause fever. Then group I, II, III respectively as a group extract dose of $720 \mathrm{mg} / \mathrm{kgBW}, 1080 \mathrm{mg} / \mathrm{kgBB}$ and $1440 \mathrm{mg} / \mathrm{KgBB}$. Group IV was positive control (paracetamol $6.3 \mathrm{mg} / 100 \mathrm{~g} \mathrm{BW}$ ) and group $\mathrm{V}(\mathrm{CMC}-\mathrm{Na} 0.5 \%)$. Everything is given orally on a single dose. Temperature measurements were carried out before administering the DPT-Hb-Hib vaccine, 3 hours after the administration of DPT-Hb-Hib vaccine and 30 minutes after treatment until 240 minutes. The results showed that there were significant differences between the negative control group and the dose group I, II, III at 90 to 240 minutes. Conclusions can be drawn that the ethanolic extract of $70 \%$ of srikaya leaves has antipyretic effects on male rats in Wistar strain in vivo.
\end{abstract}

Keywords: antipyretic, leaf extracts custard apples (Annona squamosa L), vaccine DPT-Hb-Hib.

\section{PENDAHULUAN}

Suhu demam atau pireksia merupakan gejala dari suatu penyakit. Penyakit infeksi seperti demam berdarah, tifus, malaria, peradangan hati, dan penyakit infeksi lain merupakan contoh penyakit yang sering mempunyai gejala demam. Dampak negatif demam antara lain dehidrasi, kekurangan 
oksigen, kerusakan saraf, rasa tidak nyaman seperti sakit kepala, nafsu makan menurun (anoreksia), lemas, dan nyeri otot. Untuk mengurangi dampak negatif ini maka demam perlu diobati dengan antipiretik (Arifianto \& Hariadi, 2007). Derajat suhu yang dapat dikatakan demam adalah suhu rektal $\geq 38,0^{\circ} \mathrm{C}$ atau suhu mulut $\geq 37,5^{\circ} \mathrm{C}$ atau suhu aksila $\geq 37,2^{\circ} \mathrm{C}$ (Kaneshiro N.K. dan Zieve D., 2010).

Obat-obat yang dapat menurunkan demam disebut sebagai obat-obat antipiretik. Obatobat yang digunakan untuk mengatasi demam antara lain parasetamol, asetosal, fenasetin, dan antipirin (Tjay \& Rahardja, 2002). Obatobat tersebut dengan penggunaan jangka panjang dan berlebihan dapat menyebabkan kerusakan hati dan perdarahan pada saluran cerna (Ganiswarna, 2007).

Munculnya banyak permasalahan yang terkait dengan mengkonsumsi obat sintetik memicu maraknya penelitian tanaman obat tradisional untuk pencegahan dan pengobatan demam. Secara eksperimental aktivitas antipiretik suatu bahan atau senyawa dapat diketahui dengan melakukan percobaan pada hewan uji, baik secara in vivo maupun in vitro (Wijoyo, 2003).

Penelitian yang dilakukan oleh (Wandasari, Ruslan, \& Kusmardiyani, 2007) menunjukan bahwa daun srikaya mengandung alkaloid, glikosida sianogen, flavonoid, fenol, saponin, dan terpenoid. Flavonoid menunjukan lebih dari seratus macam bioaktivitas. Bioaktivitas yang ditunjukkan antara lain efek antipiretik, analgetik, dan antiinflamasi (Wijayakusuma, 2001). Flavonoid dapat menghambat siklooksigenase, jenis flavonoid yang menghambat jalur COX adalah flavon. Kemungkinan besar efek antipiretik disebabkan karena penghambatan siklooksigenase yang merupakan langkah pertama pada jalur eikosanoid seperti prostaglandin dan tromboksan (Robinson T. , 2001).

Berdasarkan uraian diatas peneliti ingin membuktikan aktivitas efek antipiretik ekstrak daun srikaya yang diuji pada tikus jantan galur wistar. Dosis ekstrak mengacu pada penelitian terdahulu tentang uji efek antipiretik menggunakan daun tumbuhan tembelekan (Lantana camara L) yang mengandung flavonoid dengan dosis (720 $\mathrm{mg} / \mathrm{kgBB} ; 1080 \mathrm{mg} / \mathrm{kgBB} ; 1440 \mathrm{mg} / \mathrm{kgBB}$ ) yang diharapkan mempunyai efek antipiretik. Ekstrak daun srikaya bisa dijadikan alternatif untuk terapi penurunan demam selain obat sintesis seperti parasetamol.

\section{METODE}

Penelitian ini menggunakan metode eksperimen dengan rancangan penelitian post test only randomized control group design. Penelitian menggunakan 25 ekor tikus jantan galur wistar, yang dikelompokkan menjadi 5 kelompok secara acak dan tiap kelompok terdiri dari 5 ekor tikus. Setiap kelompok diinjeksi dengan vaksin DPT-Hb-Hib 0,3 ml secara I.M untuk menimbulkan demam. 
Kemudian kelompok I, II, III secara berturutturut sebagai kelompok ekstrak dosis 720 $\mathrm{mg} / \mathrm{kgBB}, \quad 1080 \mathrm{mg} / \mathrm{kgBB}$ dan 1440 $\mathrm{mg} / \mathrm{KgBB}$. Kelompok IV kontrol positif (parasetamol 6,3 $\mathrm{mg} / 100 \quad \mathrm{~g} \quad \mathrm{BB}$ ) dan kelompok V sebagai kontrol negatif (CMC$\mathrm{Na} 0,5 \%)$. Semuanya diberikan secara peroral secara single dose. Pengukuran suhu dilakukan sebelum pemberian vaksin DPTHb-Hib, 3 jam setelah pemberian vaksin DPT-Hb-Hib dan 30 menit sekali setelah perlakuan sampai menit 240 .

Alat-alat yang digunakan dalam penelitian ini yaitu timbangan analitik merk Mettler Toledo, erlenmeyer, glassware merk Pyrex, jarum suntik, sonde tikus, tabung reaksi, vakum evaporator merk Heidolph, hot plate, waterbath, kertas saring dan termometer digital. Bahan yang digunakan yaitu daun srikaya, etanol $70 \%$, aquades, parasetamol, CMC-Na, vaksin DPT-Hb-Hib dan tikus jantan sebanyak 35 ekor.

Bahan yang digunakan yaitu daun srikaya (diperoleh dari Gunung Pati, Semarang), etanol $70 \%$ (Grade Laboratorium-PT. Brataco), aquades (Grade Laboratorium-PT. Brataco), parasetamol (PT Actavis), CMC-Na (Food Grade-PT. Brataco), vaksin DPT-HbHib (Biofarma) dan tikus jantan sebanyak 35 ekor.

Tahapan yang dilakukan dalam penelitian ini adalah determinasi tanaman srikaya, maserasi daun srikaya, uji skrining fitokimia, dan uji aktivitas antipiretik ekstrak daun srikaya dengan pemeriksaan suhu tubuh tikus jantan galur wistar yang telah diberikan perlakuan menggunakan termometer rektal digital dengan satuan ${ }^{\circ} \mathrm{C}$.

Data penurunan suhu rektal tikus pada menit ke 30 sampai menit ke 240 yang diperoleh diolah dengan menggunakan SPSS. Langkah pertama adalah uji normalitas menggunakan tes Kolmogorov-Smirnov. Kemudian dilanjutkan uji homogenitas menggunakan Levene test. Dari uji normalitas dan homogenitas didapatkan data berdistribusi normal dan homogen. Selanjutnya, dilakukan analisis parametrik menggunakan uji anova. Kemudian dilanjutkan dengan uji post hoc untuk membandingkan perbedaan mean antara 2 kelompok dengan nilai $\alpha=0,5$.

\section{HASIL DAN PEMBAHASAN}

Hasil determinasi tanaman adalah sebagai berikut:

$\begin{array}{ll}\text { Divisio } & \text { : Spermathophyta } \\ \text { Subdivisio } & : \text { Angiospermae } \\ \text { Kelas } & : \text { Dicotyledoneae } \\ \text { Ordo } & : \text { Annonales } \\ \text { Famili } & \text { : Annonaceae } \\ \text { Genus } & \text { : Annona } \\ \text { Spesies } & \text { : Annona squamosa } \mathrm{L}\end{array}$

Pada penelitian ini hasil pengukuran suhu tubuh tikus jantan galur wistar pada kondisi awal (T1) menunjukan suhu rata-rata kelompok perlakuan dosis $134,96{ }^{\circ} \mathrm{C}$, kelompok dosis $236,78{ }^{\circ} \mathrm{C}$, kelompok dosis 3 $36,28{ }^{\circ} \mathrm{C}$, kelompok kontrol positif $37,04{ }^{\circ} \mathrm{C}$ dan kelompok kontrol negatif $35,82^{\circ} \mathrm{C}$. Untuk 
mengetahui pengaruh antipiretik ekstrak daun srikaya (Annona squamosa L.) terhadap penurunan suhu tubuh tikus jantan galur wistar harus dilakukan pada tikus yang kondisinya dalam keadaan demam. Oleh karena itu diperlukan demam buatan untuk mendemamkan tikus yaitu dengan metode induksi vaksin. Demam setelah diberi vaksin disebabkan oleh reaksi tubuh terhadap toksin kuman yang sudah dilemahkan yang masuk ke dalam tubuh. Vaksin yang digunakan pada penelitian ini adalah vaksin DPT-HB-Hib (Widiyani, 2003). Setelah pemberian vaksin diperoleh rata-rata suhu pada masing-masing kelompok perlakuan dosis I, dosis II, dosis III, kelompok kontrol positif dan kelompok kontrol negatif secara berturut-turut $37,48{ }^{\circ} \mathrm{C}$; $37,48{ }^{\circ} \mathrm{C} ; 37,74{ }^{\circ} \mathrm{C} ; 37,94{ }^{\circ} \mathrm{C}$; dan $37,42{ }^{\circ} \mathrm{C}$. Data tersebut menunjukan terjadinya kenaikan suhu tubuh tikus akibat diinduksi vaksin DPTHb-Hib. Hasil dari uji T-test antara suhu sebelum diinduksi vaksin DPT-Hb-Hib dengan suhu setelah diinduksi vaksin menunjukan perbedaan yang signifikan dengan $\mathrm{p}<0,05$ yang artinya vaksin DPT-HbHib mampu menginduksi terjadinya demam. Vaksin DPT-Hb-Hib adalah suspensi homogen yang mengandung toksid tetanus dan difteri murni, bakteri pertusis inaktif, antigen permukaan hepatitis B (HBsAg) murni yang tidak infeksius, dan komponen Hib sebagai vaksin bakteri sub unit berupa kapsul polisakarida Haemophilus influenzae tipe $b$ tidak infeksius .

Sebagai respon terhadap rangsangan pirogenik, maka monosit, makrofag, dan selsel kupffer mengeluarkan suatu zat kimia yang dikenal sebagai pirogen endogen IL1(interleukin-1), TNFa (Tumor Necrosis Factor $\alpha$ ), IL-6 (interleukin-6), dan INF (interferon) yang bekerja pada pusat termoregulasi hipotalamus untuk meningkatkan patokan termostat. Hipotalamus mempertahankan suhu di titik patokan yang baru dan bukan di suhu normal. Sebagai contoh, pirogen endogen meningkatkan titik

Tabel 1 Karakteristik Ekstrak Etanolik 70\% daun srikaya

\begin{tabular}{clll}
\hline No & \multicolumn{1}{c}{ Parameter } & \multicolumn{1}{c}{ Ekstrak daun srikaya } \\
\hline 1 & Identitas & Nama ekstrak : Extractum Annona squamosa L. Folium \\
& & Nama tanaman : Annona squamosa L. \\
& & Bagian tanaman : Daun \\
& & Nama Indonesia : Srikaya \\
\hline 2 & Organoleptik & Bentuk & $:$ Cairan kental \\
& & Warna & $:$ hijau kehitaman \\
& & Bau & $:$ Khas \\
& & Rasa & $:$ Pahit \\
\hline 3 & Kadar Air & $7,37 \%$ & \\
\hline 4 & Rendemen & $5 \%$ & \\
\hline
\end{tabular}

Tabel 2. Hasil Skrining Fitokimia Ekstrak Daun Srikaya (Annona squamosa L.)

\begin{tabular}{ccccc}
\hline Parameter uji & Reagen & Warna & Metode & Keterangan \\
\hline Flavonoid & $\mathrm{HCl}, \mathrm{Mg}$, etanol & Merah kejinggaan & Uji tabung & Positif
\end{tabular}


patokan menjadi $38,9^{\circ} \mathrm{C}$, hipotalamus merasa bahwa suhu normal prademam sebesar $37^{\circ} \mathrm{C}$ terlalu dingin, dan organ ini memicu mekanisme-mekanisme respon dingin untuk meningkatkan suhu tubuh (Ganong, 2003). Vaksin DPT-Hb-Hib dapat menimbulkan demam dengan merangsang tubuh membentuk antibodi terhadap penyakit dipteri, pertusis, tetanus, hepatitis B dan Haemophilus influenzae tipe $b$.

Setelah tikus dibuat menjadi demam maka langkah selanjutnya setiap kelompok diberi perlakuan berupa pemberian dosis 1 , dosis 2 , dosis 3, perlakuan kontrol positif dan perlakuan kontrol negatif. Selanjutnya suhu tubuh tikus tiap kelompok diukur tiap 30

Tabel 3. Rerata pengukuran suhu tubuh tikus

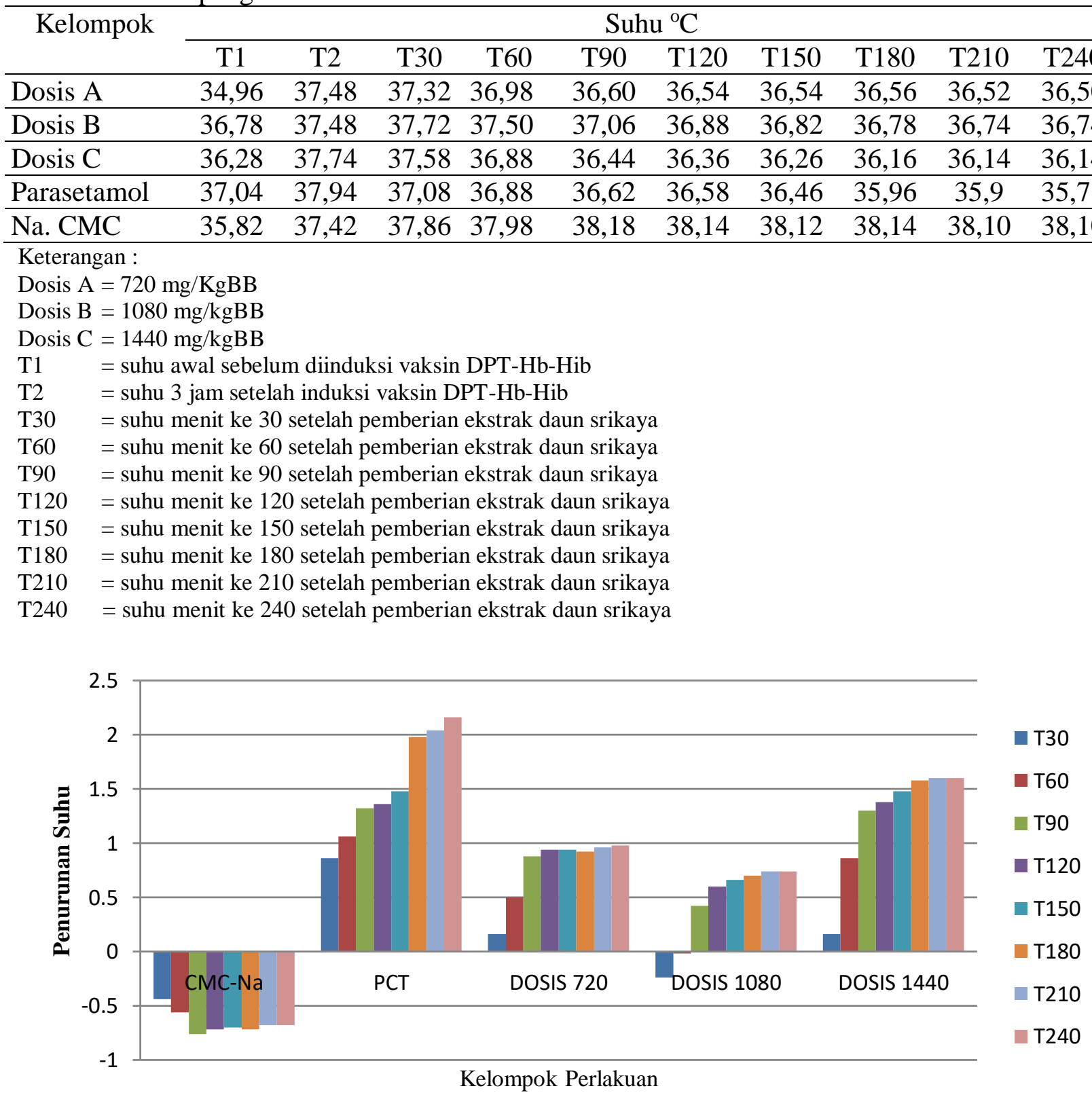

Ket : $\mathrm{T}=$ suhu, $\mathrm{PCT}=$ Parasetamol

Gambar 1. Rata-Rata Penurunan Suhu Dari Suhu Tikus Sesudah Induksi Vaksin Dikurangi Suhu Tikus Setelah Perlakuan 
menit dari menit-0 sampai menit-240. Penurunan atau penaikan suhu setelah perlakuan yang besarnya juga bervariasi untuk setiap tikus dapat dilihat pada Gambar 4.2 variasi inilah yang kemudian dianalisis untuk mengetahui ada tidaknya penurunan yang bermakna atau signifikan sebagai respon terhadap perlakuan.

Pemberian ekstrak daun srikaya (Annona squamosa L) maupun kontrol positif (Paracetamol) secara nyata dapat menurunkan suhu tubuh tikus dibandingkan dengan kontrol negatif (CMC-Na). Adapun hasil analisis menunjukkan bahwa pemberian ekstrak daun srikaya dosis $3(1440 \mathrm{mg} / \mathrm{KgBB})$ memberikan pengaruh yang signifikan terhadap penurunan suhu tubuh tikus pada waktu 60 menit setelah aplikasi perlakuan. Berarti bahwa ada perbedaan yang nyata pada jumlah rata-rata penurunan suhu tubuh tikus antara kelompok perlakuan dosis 3 ekstrak daun srikaya dengan kelompok kontrol negatif dengan nilai signifikan 0,018.

Penurunan suhu tubuh tikus pada menit ke 90, 120, 150, 180,210, dan 240 menunjukan perbedaan yang signifikan untuk semua kelompok perlakuan dosis 1 , dosis 2, dosis 3 , dan kontrol positif dibandingkan dengan kontrol negatif dengan nilai $\mathrm{p}<0,05$. Ini menunjukan bahwa kelompok dosis ekstrak terbukti memiliki aktivitas antipiretik. Sedangkan kelompok dosis 1, dosis 2 dan dosis 3 dibandingkan dengan kelompok kontrol positif tidak menunjukan perbedaan yang signifikan dengan $\mathrm{p}>0,05$. Ini menunjukan bahwa kelompok perlakuan dosis 1, dosis 2, dan dosis 3 sebanding dengan kelompok kontrol positif atau kelompok parasetamol dalam hal aktivitas penurunan demam. Namun, kelompok parasetamol menunjukan penurunan demam yang lebih cepat dibandingkan dengan kelompok dosis 1 , 2, dan 3 yakni pada menit ke 30 .

Aktivitas antipiretik dikarenakan adanya kandungan flavonoid pada ekstrak daun srikaya. Menurut (Robinson T. , 2001) flavonoid dapat menghambat enzim siklooksigenase khususnya siklooksigenase-2 yang berperan dalam biosintesis prostaglandin sehingga proses terjadinya demam terhambat. Hal tersebut juga didukung dengan hasil penelitian (Kalay S., Bodhi W., \& Yamlean P., 2014) dan penelitian (Suwertayasa, Bodhy, \& Edy, 2013) yang menyatakan bahwa flavonoid memiliki aktivitas antipiretik.

Sifat antipiretik flavanoid berasal dari mekanismenya yang menghambat pelepasan asam arakhidonat dan sekresi enzim lisosim dari sel neutrofil dan sel endhotelial dan juga menghambat fase proliferasi dan fase eksudasi dari proses inflamasi. Terhambatnya pelepasan asam arakhidonat dari sel inflamasi akan menyebabkan kurang tersedianya substrat arakhidonat bagi jalur siklooksigenase dan lipooksigenase, yang pada akhirnya akan menekan jumlah prostaglandin, prostasiklin, endoperoksida, asam hidroksatetraienoat, dan leukotrin. Disisi lain penekanan jumlah tersebut mempengaruhi proses radang, dan juga migrasi leukosit, yang akan berpengaruh 
pada penekanan peningkatan jumlah limfosit (Sabir, 2013).

\section{KESIMPULAN}

Ekstrak daun srikaya mempunyai aktivitas sebagai antipiretik pada tikus jantan galur wistar dan aktivitas antipiretik ekstrak daun srikaya aktivitas sama dengan aktivitas antipiretik obat paracetamol.

\section{DAFTAR PUSTAKA}

Arifianto, \& Hariadi. (2007). Demam. Retrieved April 19, 2015, from www.sehatgroup.web.id.

Ganiswarna, S. (2007). Farmakologi dan Terapi Edisi 5. Jakarta: Departemen Farmakologi dan Terapetik, Fakultas Kedokteran UI.

Ganong, W. (2003). Buku Ajar Fisiologi Kedokteran Edisi 5. Jakarta: EGC.

Kalay S., Bodhi W., \& Yamlean P. (2014). Uji Efek Antipiretik Ekstrak Etanol Daun Prasman (Eupatorium Tripinerve Vahl.) pada Tikus Jantan Galur Wistar (Rattus Norvegicus L.) yang Diinduksi Vaksin DTP-Hb. Pharmacon.
Kaneshiro N.K. dan Zieve D. (2010, October 29). Fever.

Robinson, T. (2001). Kandungan Organik Tumbuhan Tinggi Edisi 6. Bandung: Institut Teknologi Bandung.

Sabir, A. (2013). Pemanfaatan Flavonoid di Bidang Kedokteran Gigi. Dental Journal.

Suwertayasa, I., Bodhy, W., \& Edy, H. (2013). Uji Antipiretik Ekstrak Etanol Daun Tembelekan (Latana Camara L.) pada Tikus Jantan Galur Wistar. Manado: Universitas Sam Ratulangi.

Tjay, T., \& Rahardja, K. (2002). Obat-obat Penting: Khasiat, Penggunaan, dan Efekefek Sampingnya Edisi VI. Jakarta: PT. Elex Media Komputindo.

Wandasari, F., Ruslan, K., \& Kusmardiyani, S. (2007). Telaah Fitokimia Daun Srikaya (Anona Squamosa L.) yang berasal dari dua lokasi tumbuh. Bandung: Sekolah Farmasi ITB.

Wijayakusuma, H. (2001). Penyembuhan dengan Bawang Putih dan Bawang Merah. Jakarta: Milenia Popular.

Wijoyo, Y. (2003). Antaraksi sari wortel dengan paracetamol. Jogjakarta: Universitas Sanata Dharma. 